\title{
PHYSIOLOGICAL VARIATIONS OF SERUM BIOCHEMICAL PROFILE IN QUARTER HORSE MARES AT PERIPARTUM AND IN THEIR NEONATAL FOALS
}

\author{
VARIAÇÕES FISIOLÓGICAS NO PERFIL BIOQUÍMICO SÉRICO DE ÉGUAS \\ QUARTO DE MILHA NO PERIPARTO E POTROS NEONATOS
}

\author{
Fernando Cristino BARBOSA ${ }^{1}$; Matheus Vicente da SILVA ${ }^{2}$; Priscila Cristina COSTA ${ }^{3}$; \\ Rafael Rocha de SOUZA ${ }^{4}$; Ednaldo Carvalho GUIMARÃES ${ }^{1,5}$; Antonio Vicente MUNDIM ${ }^{\mathbf{1}}$ \\ 1. Professor da Faculdade de Medicina Veterinária, Universidade Federal de Uberlândia - UFU, Uberlândia-MG, Brasil; 2. Graduando \\ em Medicina Veterinária, Faculdade de Medicina Veterinária, Universidade Federal de Uberlândia - UFU, Uberlândia-MG, Brasil; 3. \\ Residente do Programa de Residência Uniprofissional em Medicina Veterinária - Patologia Clínica Veterinária; 4. Mestrando do \\ Programa de Pós-Graduação em Ciências Veterinárias, Universidade Federal de Uberlândia - UFU, Uberlândia, MG, Brasil; 5. Professor \\ da Faculdade de Matemática, Universidade Federal de Uberlândia - UFU, Uberlândia-MG, Brasil.
}

\begin{abstract}
The objectives of this study were to evaluate the serum biochemical profile in Quarter Horse mares in their peripartum, and neonates on their birth date, and to compare the values obtained for male and female foals, as well as values obtained for foals and mares on the day of delivery. Forty one adult, pregnant mares and their respective offspring on the day of delivery were analyzed, totaling 82 animals. Two samples of blood were collected from the mares, seven days before and on the day of delivery. From the foals, blood collection was performed on the day of their birth about $12 \mathrm{~h}$ after colostrum ingestion. The samples were centrifuged and the serum stored at $-20^{\circ} \mathrm{C}$ for analyses. Each sample was used to determine the serum concentrations proteins, metabolites, minerals and enzymes. Physiological changes caused by peripartum led to higher serum total protein, albumin, and globulins on the day of delivery. Serum concentration of triglycerides and calcium /phosphorus ratio were greater seven days before delivery; iron concentration was higher than reference ranges in both moments of evaluation. In foals, albumin serum concentrations, albumin/globulins ratio, and aspartate aminotransferase remained below reference ranges. In foals, there was no influence of sex in the serum biochemical profile. When results obtained for foals on their birth date were compared with those obtained for the mares on the delivery day, cholesterol, triglycerides, phosphorus, iron, alkaline phosphatase, and gamma glutamyltransferase were higher in foals, and total protein, albumin, globulins, urea nitrogen, calcium/phosphorus ratio, and aspartate aminotransferase were higher in mares. Results showed variations in serum biochemistry in peripartum mares and neonates, as well as in the comparison between foals and mares on the day of delivery. Clinically, serum biochemistry values for peripartum mares and neonates should be considered in the analysis of laboratory results of tests carried out in this period.
\end{abstract}

KEYWORDS: Clinical biochemistry. Pregnancy. Parturion. Birth. Colostrum.

\section{INTRODUCTION}

In horse clinical practice, peripartum is one of the most important phases for mares, a period that lasts from the three weeks before delivery to the first month after it. For foals, the neonatal period, which correspond to the first days of life, is highly important. At that moment, these animals are more susceptible to infectious and metabolic diseases, and to failure in the transfer of passive immunity.

Mares in their peripartum and newborn foals are predisposed to a series of hematological and serum biochemistry changes, once the hormone dynamics in this period and at the beginning of lactation drastically change energy metabolism (OUSEY, 2004; BERG; MCNAMARA; KEISLER, 2007; AOKI; ISHII, 2012). Metabolism changes during pregnancy are complex events and are consequences of fetal development, changes in the structure of body of the mother, such as increase in blood volume, expansion of the uterus, formation of the placenta, and increased size of the mammary glands (BROLIO et al., 2010; MARIELLA et al., 2014). The placenta is the main structure responsible for adequate maintenance of fetal electrolyte equilibrium and excretion of residues. Therefore, the concentration of electrolytes and other compounds in the newborn reflect placenta function or blood biochemistry of the mother, instead of renal function of the newborn (BROLIO et al., 2010).

The neonatal period is the most important moment in the development of the animal body, as the adaptation to the external environment and beginning of rapid growth leads to important physiological changes in serum biochemistry and 
metabolites (AXON; PALMER, 2008; HOWARD et al., 2008).

Although horses start to develop their immune function in the womb of the mother, their immunity is inadequate when they are born, as they are completely dependent on colostrum ingestion. The high susceptibility of these animals to infections in the neonatal period has been associated with failure in the transfer of passive immunity (GIGUÈRE; POLKES, 2005; FAVERO et al., 2011). Colostrum is the first secretion of the mammary gland. In mare colostrum, IgG is the predominant immunoglobulin and it is the main source of immunity to the newborn (CHAVATTE, 1997; GIGUÈRE; POLKES, 2005). The foal has to ingest colostrum in the first two hours of life. After six hours, immunoglobulins may be found in the serum, and after 18 hours, serum concentrations are close to those of the mother (JEFFCOTT, 1974; FAVERO et al., 2011). It is estimated that 2.9 to $25 \%$ of the foals show failure in the transfer of passive immunity, which is attributed to inadequate immunoglobulin concentration in the colostrum, premature lactation, insufficient colostrum ingestion, stress, and inadequate intestinal absorption (CRISMAN; SCARRATT, 2008).

Several studies analyzed the hematological and serum biochemical profiles of Quarter Horse, Thoroughbred, Saddlebred, Standardbred, and Morgan pregnant mares (HARVEY et al., 2005), Brazilian Sport Horses and Bretons (OROZCO et al., 2007), Carthusian strain (SATUÉ et al., 2010), Percherons and Bretons (AOKI; ISHII, 2012), Spanish breed (MUÑOZ et al., 2012), Spanish purebreds (SATUÉ; MONTESINOS, 2013), Standardbreds (MARIELLA et al., 2014), Quarter Horses (MÁRQUEZ et al., 2014), and Brazilian Sport Horse foals (HOWARD et al., 2008), reporting divergent results.

It is important to know the physiological variations in serum biochemistry in order to determine diagnosis, prognosis and evolution of disease; physiological adaptations to pregnancy; pathological conditions of pregnancy; and possible failure in the transfer of passive immunity in foals (CRISMAN; SCARRATT, 2008; MUÑOZ et al., 2012).

Serum biochemistry has been demonstrated to be an important tool to analyze the physiological changes to pregnancy in mares and neonatal period in foals, as well as changes in serum constituents as a function of the breed. The objective of this study was to evaluate the serum biochemical profile of Quarter Horse mares in their peripartum and foals on the day of their birth, and to compare values obtained for male and female foals, and values obtained for foals with those obtained for mares on the day of delivery.

\section{MATERIAL AND METHODS}

Forty one adult, female, pregnant mares and their respective offspring were used, totaling 82 animals. Mares were kept in Tifton 85 pastures, with water ad libitum, and had access to a covered trough for mineral supplementation. Mares were vaccinated and dewormed according to the calendar recommended for horses.

Two samples of blood were collected from the mares 7 days before (D-7) and on the day of parturition (Dp). From the foals, collection was carried out on their birth, about $12 \mathrm{~h}$ after colostrum ingestion, according to the management of the animals in the farm. Five $\mathrm{mL}$ of blood were collected from each animal in Vacutainer ${ }^{\circledR}$ tubes without an anticoagulant, by puncture of the jugular vein. After collection and complete coagulation of the blood, samples were sent to the clinical analysis laboratory at the Veterinary Hospital of Universidade Federal de Uberlândia (UFU) in isothermal boxes. Immediately after arrival in the laboratory, blood samples were centrifuged at $720 \mathrm{~g}$ for $10 \mathrm{~min}$, and serum was transferred to Eppendorf microtubes to be stored at $-20^{\circ} \mathrm{C}$, for no more than $48 \mathrm{~h}$, until the moment of analysis.

The following tests were carried out in each of the samples: concentrations of total protein (TP), albumin (Alb), cholesterol (Cho), triglycerides (TG), creatinine (Cre), blood urea nitrogen (BUN), calcium $(\mathrm{Ca})$, phosphorus $(\mathrm{P})$, iron $(\mathrm{Fe})$, aspartate aminotransferase (AST), alanine aminotransferase (ALT), alkaline phosphatase (ALP), and gammaglutamyltransferase (GGT). All samples were processed in an automatic multichannel analyzer Labmax Plenno, calibrated beforehand with calibra $\mathrm{H}$, and tested with universal control serum (Qualitrol), using Labtest Diagnóstica ${ }^{\circledR}$ commercial kits. Serum globulins concentration (Glb) was calculated by subtracting albumin from total serum protein; albumin/globulins ratio (A/G) was calculated by dividing the albumin results by globulin ones; and the $\mathrm{Ca} / \mathrm{P}$ ratio was obtained by dividing calcium by phosphorus concentrations.

Data from each variable were analyzed by Shapiro-Wilk to assess normality. Data with normal distribution were subjected to Student $t$ test. Data with non-normal distribution were analyzed by Wilcoxon test. For the remaining cases, $t$ test for independent samples or Mann-Whitney test were used for variables with normal or non-normal 
distribution, respectively. All statistical analyses were carried out considering 5\% as the significance level.

This research project was approved by the Ethics Commission on the Use of Animals (CEUA) from Federal University of Uberlândia, protocol no. $103 / 15$.

\section{RESULTS}

Serum biochemistry values for protein in mares showed higher concentrations of TP, Alb, and Glb on the day of delivery compared with the results before delivery. Alb showed lower results and globulins were above reference range for horses, before and after parturition. The A/G ratio remained constant and slightly below the reference range for the species in the two moments analyzed (Table 1).

In the lipid profile, serum concentration of TG was greater in the seven days before delivery $(\mathrm{p}<0.000)$, and higher than the reference range for horses. In the mineral metabolism profile, the $\mathrm{Ca} / \mathrm{P}$ ratio was higher seven days before delivery $(\mathrm{p}<0.014)$. $\mathrm{P}$ was inside the reference range, whereas $\mathrm{Ca}$ on the day of delivery was slightly below the reference range. $\mathrm{Fe}$ values were superior to the reference range in the two moments analyzed (Table 1).

Table 1. Mean, standard deviation (SD), $p$ values and reference ranges of serum biochemistry in Quarter Horse mares seven days before (D-7) and on the day of delivery (Dp).

\begin{tabular}{|c|c|c|c|c|}
\hline $\begin{array}{l}\text { Biochemical } \\
\text { constituents }\end{array}$ & $\frac{\mathrm{D}-7(\mathrm{n}=41)}{\text { Mean } \pm S D}$ & $\begin{array}{c}\text { Dp }(n=41) \\
\text { Mean } \pm \text { SD }\end{array}$ & $P$ value & $\begin{array}{c}\text { Reference } \\
\text { ranges* }\end{array}$ \\
\hline $\mathrm{TP}\left(\mathrm{g} \mathrm{dL}^{-1}\right)$ & $7.2 \pm 0.9$ & $7.8 \pm 1.2$ & 0.001 & $5.2-7.9$ \\
\hline $\operatorname{Alb}\left(\mathrm{g} \mathrm{dL}^{-1}\right)$ & $2.3 \pm 0.2$ & $2.5 \pm 0.4$ & 0.001 & $2.6-3.7$ \\
\hline $\operatorname{Glb}\left(\mathrm{g} \mathrm{dL}^{-1}\right)$ & $4.9 \pm 0.9$ & $5.3 \pm 1.0$ & 0.013 & $2.6-4.0$ \\
\hline $\mathrm{A} / \mathrm{G}$ ratio & $0.5 \pm 0.1$ & $0.5 \pm 0.1$ & 0.211 & $0.6-1.4$ \\
\hline Cho $\left(\mathrm{mg} \mathrm{dL}^{-1}\right)$ & $97.9 \pm 3.5$ & $96.6 \pm 30.9$ & 0.582 & $75-150$ \\
\hline $\mathrm{TG}\left(\mathrm{mg} \mathrm{dL}^{-1}\right)$ & $59.1 \pm 2.1$ & $33.1 \pm 23.2$ & 0.000 & $6.0-44.0$ \\
\hline Cre $\left(\mathrm{mg} \mathrm{dL}^{-1}\right)$ & $1.2 \pm 0.4$ & $1.1 \pm 0.3$ & 0.361 & $0.9-1.9$ \\
\hline $\operatorname{BUN}\left(\mathrm{mg} \mathrm{dL}^{-1}\right)$ & $17.7 \pm 8.0$ & $19.1 \pm 8.0$ & 0.441 & $10.0-24.0$ \\
\hline $\mathrm{Ca}\left(\mathrm{mg} \mathrm{dL}^{-1}\right)$ & $11.4 \pm 1.5$ & $11.0 \pm 1.9$ & 0.262 & $11.2-13.6$ \\
\hline $\mathrm{P}\left(\mathrm{mg} \mathrm{dL}^{-1}\right)$ & $3.4 \pm 0.3$ & $3.6 \pm 1.0$ & 0.183 & $3.1-5.6$ \\
\hline $\mathrm{Ca} / \mathrm{P}$ ratio & $3.4 \pm 0.4$ & $3.1 \pm 0.5$ & 0.014 & NIL \\
\hline $\mathrm{Fe}\left(\mu \mathrm{g} \mathrm{dL}^{-1}\right)$ & $179.3 \pm 58.3$ & $192.6 \pm 89.6$ & 0.246 & $73-140$ \\
\hline $\operatorname{AST}\left(\mathrm{U} \mathrm{L}^{-1}\right)$ & $209.5 \pm 73.6$ & $196.3 \pm 74.3$ & 0.586 & $226-336$ \\
\hline $\operatorname{ALT}\left(\mathrm{U} \mathrm{L}^{-1}\right)$ & $17.4 \pm 13.8$ & $21.1 \pm 21.5$ & 0.335 & $3.0-23.0$ \\
\hline $\operatorname{ALP}\left(\mathrm{U} \mathrm{L}^{-1}\right)$ & $240.8 \pm 137.5$ & $242.7 \pm 104.8$ & 0.602 & $138-251$ \\
\hline $\operatorname{GGT}\left(\mathrm{UL}^{-1}\right)$ & $20.0 \pm 13.7$ & $20.1 \pm 10.1$ & 0.524 & $4.0-44.0$ \\
\hline
\end{tabular}

$\mathrm{TP}=$ Total protein, $\mathrm{Alb}=$ albumin, $\mathrm{Glb}=$ globulins, $\mathrm{A} / \mathrm{G}=$ albumin/globulins, $\mathrm{Cho}=$ cholesterol, $\mathrm{TG}=$ triglycerides, Cre $=\mathrm{creatinine}$, $\mathrm{BUN}=$ urea $(\mathrm{mg} / \mathrm{dL}) \times 0.467, \mathrm{Ca}=$ calcium, $\mathrm{P}=$ phosphorus, $\mathrm{Fe}=$ iron, $\mathrm{AST}=$ aspartate aminotransferase, ALT= alanine aminotransferase, ALP=alkaline phosphatase, GGT= gamma-glutamyltransferase, NIL: Not informed in the literature. *ORSINI; DIVERS (2003): Reference range for adults animals.

Most of the serum biochemistry constituents in foals (males and females) were inside the reference range for one-day old foals, according to Orsini and Divers (2003), except for Alb means, A/G ratio, and AST, which were below the limits cited by these authors (Table 2).

There was no significant difference $(p>0.05)$ in the comparison of the serum biochemistry constituents for male and female foals (Table 2).

When values recorded for foals on the day of their birth after colostrum ingestion were compared with those of mares on the day of delivery. Higher results were observed for Cho, TG, P, Fe, ALP, and GGT in foals. In mares, higher values were recorded for TP, Alb, Glb, BUN, Ca/P ratio, and AST (Table 3). 
Table 2. Mean, standard deviation (SD), $p$ values and reference ranges of serum biochemistry for Quarter Horse neonates on the day of their birth according to sex.

\begin{tabular}{|c|c|c|c|c|c|}
\hline \multirow{2}{*}{$\begin{array}{l}\text { Biochemical } \\
\text { constituents }\end{array}$} & $\begin{array}{l}\text { Male } \\
(\mathrm{n}=17)\end{array}$ & $\begin{array}{l}\text { Female } \\
(\mathrm{n}=24)\end{array}$ & $\begin{array}{l}\text { Male and Female } \\
(\mathrm{n}=41)\end{array}$ & \multirow[t]{2}{*}{$P$ value } & \multirow{2}{*}{$\begin{array}{l}\text { Reference } \\
\text { ranges }\end{array}$} \\
\hline & Mean \pm SD & Mean \pm SD & Mean \pm SD & & \\
\hline $\mathrm{TP}\left(\mathrm{g} \mathrm{dL}^{-1}\right)$ & $6.5 \pm 0.7$ & $6.7 \pm 1.2$ & $6.6 \pm 1.0$ & 0.787 & $4.3-8.1^{1}$ \\
\hline $\operatorname{Alb}\left(\mathrm{g} \mathrm{dL}^{-1}\right)$ & $2.2 \pm 0.3$ & $2.2 \pm 0.3$ & $2.2 \pm 0.3$ & 0.957 & $2.5-3.6^{1}$ \\
\hline $\operatorname{Glb}\left(\mathrm{g} \mathrm{dL}^{-1}\right)$ & $4.3 \pm 0.9$ & $4.5 \pm 1.1$ & $4.4 \pm 1.0$ & 0.892 & $1.5-4.6^{1}$ \\
\hline $\mathrm{A} / \mathrm{G}$ ratio & $0.5 \pm 0.2$ & $0.5 \pm 0.1$ & $0.5 \pm 0.1$ & 0.978 & $0.6-1.9^{1}$ \\
\hline Cho $\left(\mathrm{mg} \mathrm{dL}^{-1}\right)$ & $189.3 \pm 55.7$ & $174.4 \pm 49.2$ & $180.7 \pm 51.9$ & 0.416 & $110-562^{1}$ \\
\hline $\mathrm{TG}\left(\mathrm{mg} \mathrm{dL}^{-1}\right)$ & $50.3 \pm 29.7$ & $42.9 \pm 28.4$ & $46.0 \pm 28.8$ & 0.448 & $30-193^{1}$ \\
\hline Cre $\left(\mathrm{mg} \mathrm{dL}^{-1}\right)$ & $1.2 \pm 0.5$ & $1.2 \pm 0.4$ & $1.2 \pm 0.5$ & 0.685 & $1.2-4.3^{1}$ \\
\hline $\operatorname{BUN}\left(\mathrm{mg} \mathrm{dL}^{-1}\right)$ & $14.5 \pm 6.2$ & $16.4 \pm 7.8$ & $15.6 \pm 7.1$ & 0.386 & $9.0-40.0^{1}$ \\
\hline $\mathrm{Ca}\left(\mathrm{mg} \mathrm{dL}^{-1}\right)$ & $11.8 \pm 2.0$ & $11.6 \pm 1.3$ & $11.7 \pm 1.6$ & 0.315 & $9.7-13.7^{1}$ \\
\hline $\mathrm{P}\left(\mathrm{mg} \mathrm{dL}^{-1}\right)$ & $5.3 \pm 1.5$ & $5.4 \pm 1.8$ & $5.4 \pm 1.7$ & 0,892 & $3.1-5.6^{2}$ \\
\hline $\mathrm{Ca} / \mathrm{P}$ ratio & $2.4 \pm 0.9$ & $2.4 \pm 0.8$ & $2.4 \pm 0.8$ & 1.000 & NIL \\
\hline $\mathrm{Fe}\left(\mu \mathrm{g} \mathrm{dL}^{-1}\right)$ & $289.8 \pm 111.6$ & $264.8 \pm 126.5$ & $275.4 \pm 119.5$ & 0.551 & $78-348^{1}$ \\
\hline $\operatorname{AST}\left(\mathrm{U} \mathrm{L}^{-1}\right)$ & $131.5 \pm 26.7$ & $141.0 \pm 44.2$ & $137.0 \pm 37.7$ & 0.787 & $146-340^{1}$ \\
\hline $\operatorname{ALT}\left(\mathrm{U} \mathrm{L}^{-1}\right)$ & $16.9 \pm 8.9$ & $15.2 \pm 9.7$ & $16.0 \pm 9.3$ & 0.416 & $0-49.0^{1}$ \\
\hline $\operatorname{ALP}\left(\mathrm{U} \mathrm{L}^{-1}\right)$ & $1638.3 \pm 752.0$ & $1543.9 \pm 749.9$ & $1584.0 \pm 742.6$ & 0.957 & $861-2671^{1}$ \\
\hline $\operatorname{GGT}\left(\mathrm{U} \mathrm{L}^{-1}\right)$ & $27.1 \pm 10.9$ & $28.4 \pm 9.7$ & $27.9 \pm 10.1$ & 1.000 & $18.0-43.0^{1}$ \\
\hline
\end{tabular}

$\mathrm{TP}=$ Total protein, $\mathrm{Alb}=$ albumin, $\mathrm{Glb}=$ globulins, $\mathrm{A} / \mathrm{G}=$ albumin/globulins, Cho $=$ cholesterol, $\mathrm{TG}=$ triglycerides, Cre $=\mathrm{creatinine}$, $\mathrm{BUN}=$ urea $(\mathrm{mg} / \mathrm{dL}) \times 0.467, \mathrm{Ca}=$ calcium, $\mathrm{P}=$ phosphorus, $\mathrm{Fe}=$ iron, $\mathrm{AST}=$ aspartate aminotransferase, $\mathrm{ALT}=$ alanine aminotransferase, $\mathrm{ALP}=$ alkaline phosphatase, GGT= gamma-glutamyltransferase, NIL: Not informed in the literature. ${ }^{1}$ - ORSINI; DIVERS (2003): Reference ranges for one-day old foals. ${ }^{2}$ - ORSINI; DIVERS (2003): Reference ranges for adults animals.

Table 3. Mean, standard deviation (SD), variation and $p$ values of serum biochemistry for Quarter Horse mares on the day of delivery (Dp) and for neonates on the day of their birth.

\begin{tabular}{lcccc}
\hline Biochemical & Mares Dp $(\mathrm{n}=41)$ & Foals $(\mathrm{n}=41)$ & Variation $(\%)$ & \multirow{2}{*}{$P$ value } \\
\cline { 2 - 4 } constituents & Mean $\pm \mathrm{SD}$ & Mean $\pm \mathrm{SD}$ & Mares/Foals & \\
\hline TP $\left(\mathrm{g} \mathrm{dL}^{-1}\right)$ & $7.8 \pm 1.2$ & $6.6 \pm 1.0$ & -15.4 & 0.000 \\
Alb $\left(\mathrm{g} \mathrm{dL}^{-1}\right)$ & $2.5 \pm 0.4$ & $2.2 \pm 0.3$ & -12.0 & 0.000 \\
$\mathrm{Glb}\left(\mathrm{g} \mathrm{dL}^{-1}\right)$ & $5.3 \pm 1.0$ & $4.4 \pm 1.0$ & -17.0 & 0.000 \\
A/G ratio & $0.5 \pm 0.1$ & $0.5 \pm 0.1$ & 00.00 & 0.521 \\
Cho $\left(\mathrm{mg} \mathrm{dL}^{-1}\right)$ & $96.6 \pm 30.9$ & $180.7 \pm 51.9$ & +87.1 & 0.000 \\
TG $\left(\mathrm{mg} \mathrm{dL}^{-1}\right)$ & $33.1 \pm 23.2$ & $46.0 \pm 28.8$ & +39.0 & 0.023 \\
$\mathrm{Cre}\left(\mathrm{mg} \mathrm{dL}^{-1}\right)$ & $1.1 \pm 0.3$ & $1.2 \pm 0.5$ & +9.1 & 0.241 \\
$\mathrm{BUN}\left(\mathrm{mg} \mathrm{dL}^{-1}\right)$ & $19.1 \pm 8.0$ & $15.6 \pm 7.1$ & -18.3 & 0.022 \\
$\mathrm{Ca}\left(\mathrm{mg} \mathrm{dL}^{-1}\right)$ & $11.0 \pm 1.9$ & $11.7 \pm 1.6$ & +6.4 & 0.089 \\
$\mathrm{P}\left(\mathrm{mg} \mathrm{dL}^{-1}\right)$ & $3.6 \pm 1.0$ & $5.4 \pm 1.7$ & +50.0 & 0.000 \\
$\mathrm{Ca} / \mathrm{P} \mathrm{ratio}$ & $3.1 \pm 0.5$ & $2.4 \pm 0.8$ & -29.0 & 0.000 \\
Fe $\left(\mu \mathrm{g} \mathrm{dL}^{-1}\right)$ & $192.6 \pm 89.6$ & $275.4 \pm 119.5$ & +43.0 & 0.001 \\
AST $\left(\mathrm{U} \mathrm{L} \mathrm{L}^{-1}\right)$ & $196.3 \pm 74.3$ & $137.0 \pm 37.7$ & -30.2 & 0.000 \\
ALT $\left(\mathrm{U} \mathrm{L} \mathrm{L}^{-1}\right)$ & $21.4 \pm 21.5$ & $16.0 \pm 9.3$ & -25.2 & 0.250 \\
ALP $\left(\mathrm{U} \mathrm{L} \mathrm{L}^{-1}\right)$ & $242.7 \pm 104.8$ & $1584.0 \pm 742.6$ & +552.7 & 0.000 \\
GGT $\left(\mathrm{U} \mathrm{L}^{-1}\right)$ & $20.1 \pm 10.1$ & $27.9 \pm 10.1$ & +38.8 & 0.000 \\
\hline
\end{tabular}

$\mathrm{TP}=$ Total protein, $\mathrm{Alb}=$ albumin, $\mathrm{Glb}=$ globulins, $\mathrm{A} / \mathrm{G}=$ albumin/globulins, $\mathrm{Cho}=$ cholesterol, $\mathrm{TG}=$ triglycerides, $\mathrm{Cre}=\mathrm{creatinine}$, $\mathrm{BUN}=$ urea $(\mathrm{mg} / \mathrm{dL}) \times 0.467, \mathrm{Ca}=$ calcium, $\mathrm{P}=$ phosphorus, $\mathrm{Fe}=$ iron, $\mathrm{AST}=$ aspartate aminotransferase, $\mathrm{ALT}=$ alanine aminotransferase, $\mathrm{ALP}=$ alkaline phosphatase, $\mathrm{GGT}=$ gamma-glutamyltransferase. 


\section{DISCUSSION}

\section{Mares}

Several factors may influence blood biochemistry constituents, such as breed, age, sex, temperament, diet, health status, reproductive period, and physiological adaptions (CRISMAN; SCARRATT, 2008; MUÑOZ et al., 2012).

TP serum concentration depends on the increase or decrease in Alb and Glb values. The elevated values obtained for serum TP, Alb, and Glb on the day of delivery may be related to transitory blood concertation due to the loss of fluid during parturition and to the time to water ingestion after delivery. These results corroborate those reported by Aoki and Ishii (2012), who attributed the changes in protein profile to this transitory blood concentration on the day of delivery.

Dehydration due to loss of water is essentially the only case when simple hyperproteinemia occurs without changes in the protein profile or $\mathrm{A} / \mathrm{G}$ ratio. In this case, all protein fractions increase proportionally, including albumin, as water is removed from blood circulation (KANEKO; HARVEY; BRUSS, 2008). Hypoalbuminemia has to be evaluated associated with the $\mathrm{A} / \mathrm{G}$ ratio. When the $\mathrm{A} / \mathrm{G}$ remains constant and below the reference range, hypoalbuminemia is suggested (ECKERSALL, 2008), which confirms the proteinogram results for the mares obtained seven days before and on the day of delivery in the present study showing decreased Alb and increased Glb.

Serum Glb superior to the reference ranges for horses may be associated with vaccinations before delivery (in the case of the mares studied here, they were vaccinated in the $5^{\text {th }}, 7^{\text {th }}$, and $9^{\text {th }}$ month) and to possible physiological adaptations caused by pregnancy. According to Hurley and Theil (2011) and Márquez et al. (2014), the peripartum is a period in which there is a need for increased maternal antibodies to ensure the adequate transfer of passive immunity to foals.

In lipid metabolism, TG is an important nutrient and one of the main components of fatty tissue and milk. Serum levels of TG are considered an indication of their use in the body (AOKI; ISHII, 2012). Higher TG serum concentration seven days before parturition may be due to the greater mobilization of this metabolite to supply the energy demands of the body in the delivery and beginning of lactation. Therefore, the decrease in TG serum concentration on the day of delivery may be due to the greater consumption of energy by the female during delivery and beginning of lactation. These results are consistent with those found by Harvey et al. (2005) and Aoki and Ishii (2012). However, they are different from those of Mariella et al. (2014), who did not find significant difference in TG serum values in the peripartum period. The difference in the values obtained in the present study with those by Mariella et al. (2014) may be due to breed characteristics, such as the size of the animal and its muscle mass, which determine greater or lesser mobilization of the body fat.

Serum levels of $\mathrm{Ca}$ and $\mathrm{P}$ in the mares did not vary significantly in the present study. However, $\mathrm{Ca}$ mean concentration on the day of delivery was slightly lower than the reference range, probably due to the use of $\mathrm{Ca}$ in the moment of delivery in uterine and muscle contractions, and the demand for milk production, as reported by Mariella et al. (2014). A different finding was reported by Harvey et al. (2005) and Aoki and Ishii (2012), who observed lower $\mathrm{Ca}$ serum levels on the day of delivery, although inside the physiological range for horses. The $\mathrm{Ca} / \mathrm{P}$ ratio varied significantly, with lower values on the day of delivery, but it was aligned with $\mathrm{Ca}$ and $\mathrm{P}$ serum concentrations determined in the present study.

Serum $\mathrm{Fe}$ greater than the reference range for horse in the two moments analyzed were also determined by Aoki and Ishii (2012). According to these researchers, increased $\mathrm{Fe}$ concentrations may be attributed to endogenous glucocorticoids released during the physical stress of peripartum. The administration of corticosteroids in horses increases significantly Fe serum concentrations.

AST serum values were below minimum reference ranges. These results are not clinically important as they are below the minimum value. According to González and Da Silva (2006), the minimum value starts at zero.

\section{Foals}

In most animal species, total serum protein is low at the moment of birth, increasing after colostrum ingestion and immunoglobulin absorption (AXON; PALMER, 2008; BARTON, 2015). Barton (2015) shows that, according to the moment of colostrum ingestion and immunoglobulins absorption, TP serum levels vary considerably during the first 24 to $36 \mathrm{~h}$ of life. Still, according to this author, after nursing, TP serum concentration is generally superior to $6 \mathrm{~g} \mathrm{dL}^{-1}$, with $\mathrm{A} / \mathrm{G}$ ratio normal or slightly below the reference range. This was observed in the present study, with values of $6.6 \mathrm{~g}$ $\mathrm{dL}^{-1}$ for TP and Glb near the superior limit for oneday old foals (ORSINI; DIVERS, 2003), suggested 
adequate colostrum ingestion and absorption by the foals.

Alb serum concentration below the minimum reference range is attributed to the fact that foals were one-day old neonates with immature livers and low capacity of synthesis of this protein. The A/G ratio remained constant and below the reference ranges due to low albumin concentration in these animals. According to Aoki and Ishii (2012), the low Alb serum levels after birth may be related to blood dilution caused by colostrum ingestion.

The similarity in serum biochemical parameters of males and female foals may probably be due to the fact that these animals were not sexually mature.

\section{Mares/Foals}

$\mathrm{TP}$, Alb, and Glb serum concentration in foals significantly inferior to those found in mares on the day of delivery are attributed to the immaturity of the foal liver, causing reduced albumin synthesis, and to the fact that immunoglobulins had not reached the peak in the blood, at the moment of evaluation. According to Jeffcott (1974) and Favero et al. (2011), after colostrum ingestion, immunoglobulins reach a peak in $18 \mathrm{~h}$ and are found in concentrations very close to the serum of the mother. However, Lang et al. (2007) observed that $64.7 \%$ of the foals that they studied showed higher $\operatorname{IgG}$ concentration $48 \mathrm{~h}$ after birth.

In lipid profile, Cho values $87.1 \%$ and TG $39.0 \%$ superior in foals compared with mares on the delivery day may possibly be due to the ingestion of these metabolites in the fat-rich colostrum.

BUN serum concentration $18.3 \%$ inferior in foals compared with their mothers is attributed to the increased protein metabolism in mares due to the great demand for milk synthesis. The important relationship between urea concentrations and protein metabolism is widely known.

In the present study, Cre serum concentration in the foals did not differ from those of mares on the day of delivery, although results were $9.1 \%$ greater. Researchers state that Cre and BUN serum concentrations may be increased in neonates, even without evidence of renal dysfunction, as the placenta eliminates these metabolites before delivery (MORRESEY, 2005; AOKI; ISHII, 2012). Foal kidneys are somewhat immature soon after birth, making it difficult for these metabolites to be excreted. According to Barton (2015), urine elimination in foals generally
BARBOSA, F. C. et al

occurs 6 to $12 \mathrm{~h}$ after birth, also delaying the elimination of these metabolites.

In the mineral metabolism, $\mathrm{P}$ serum concentration in foals was $50.0 \%$ superior than that of mares, a difference attributed to the fact that the foals were fed milk, and $\mathrm{Ca}$ and $\mathrm{P}$ are found in the milk of mares in a concentration equal to $1 / 1$, favoring higher $\mathrm{P}$ serum concentrations in animals that are fed exclusively milk. In several occasions, animals may show $\mathrm{Ca} / \mathrm{P}$ ratios equal to 1 . Besides, the high $\mathrm{P}$ demand for milk production led to lower serum level of this mineral in females. These results were similar to those of Aoki and Ishii (2012) who stated that serum concentrations of minerals vary according to milk composition. $\mathrm{Ca} / \mathrm{P} 29.0 \%$ lower in foals was a result of the greater $\mathrm{P}$ serum concentration in this group of animals.

$\mathrm{Fe}$ serum concentration in foals was $43.0 \%$ superior to that of mares. The result corroborates the findings of Aoki and Ishii (2012), who also detected high Fe levels in foals in the first hours after birth. According to these researchers, there is no evident clinical meaning for these findings, and Fe levels reach the normal range for adults in the first $24 \mathrm{~h}$ of life. These data are important in the diagnosis of iron deficiency anemia, which is relatively frequent in foals until three months of age (AXON; PALMER, 2008).

In the present study, AST serum activity $30.2 \%$ lower in foals compared with mares is attributed to the muscle effort during uterine contractions to expel the fetus. According to Barton (2015), AST serum levels tend to be similar or inferior to adult values in the first week of life, and then reach the reference range for adult horses with growth and muscle activity.

ALP serum concentration in foals was $552.7 \%$ superior than that of mares, which may probably be due to pinocytosis and intestinal activity in the first $24 \mathrm{~h}$ of life. According to Valente et al. (2009), the mucosa of the small intestine of several animal species, including horses, is extremely rich in ALP.

Serum GGT was $38.8 \%$ greater in foals compared with their mothers. Although there is no clear reason for this difference, it may be attributed to the beginning of the liver metabolism. This result is similar to the findings of Patterson and Brown (1986), who reported that serum GGT activity in Standardbred foals was significantly superior to that of the mares. It should be emphasized that GGT levels on the day of birth is not a result of colostrum ingestion, as observed in ruminants, once mares have low levels of GGT in the colostrum (AOKI; ISHII, 2012; BARTON; LEROY, 2007). These 
higher levels in the foals, thus, may be an indication that serum GGT levels are probably a result of endogenous sources (PATTERSON; BROWN, 1986).

\section{CONCLUSIONS}

Variations in the values of the biochemical constituents of mares during their peripartum, of neonates, and of foals compared with mares on their delivery day.

There was no influence of sex in the results found for the foals. Clinically, the values of the serum biochemistry constituents found in the peripartum mares and neonate foals should be considered in the interpretation of laboratory tests carried out at these moments.

RESUMO: Os objetivos deste estudo foram avaliar o perfil bioquímico sérico de éguas no periparto e potros no dia do nascimento, e confrontar os valores obtidos para potros machos e fêmeas, e desses com as éguas no dia do parto. Foram utilizadas 41 éguas adultas, gestantes, e suas respectivas crias no dia do nascimento, totalizando 82 animais. Das éguas foram coletadas duas amostras de sangue, sete dias antes do parto e no dia do parto. Dos potros, no dia do nascimento, aproximadamente $12 \mathrm{~h}$ após ingestão do colostro. As amostras foram centrifugadas e o soro estocado à - $20^{\circ}$ $\mathrm{C}$ para análises. De cada amostra foram determinadas as concentrações séricas de proteínas, metabólitos, minerais e enzimas. Alterações fisiológicas decorrentes do periparto determinaram um quadro com maiores valores sérico das proteínas totais, albumina e globulinas no dia do parto. A concentração sérica dos triglicérides e a relação cálcio/fósforo foi maior aos sete dias antes do parto e, o ferro com valores superiores aos de referência, nos dois momentos avaliados. Nos potros as concentrações séricas da albumina, relação albumina/globulinas e aspartato aminotransferase permaneceram abaixo dos valores de referência. Não houve influencia do sexo nos valores dos constituintes bioquímicos séricos avaliados. Quando confrontados os resultados obtidos para potros, no dia do nascimento, com os das éguas no dia do parto, observou-se maiores valores do colesterol, triglicérides, fósforo, ferro, fosfatase alcalina e gama glutamiltransferase nos potros, e nas éguas maiores valores para proteínas totais, albumina, globulinas, nitrogênio ureico, relação cálcio/fósforo e aspartato aminotransferase. Os resultados revelaram variações nos valores dos constituintes bioquímicos séricos nas éguas no peripato, nos potros neonatos e dos potros em relação as éguas no dia do parto. Clinicamente, os valores dos constituintes bioquímicos séricos nas éguas no periparto e potros neonatos, devem ser considerados no momento da interpretação de resultados de análises laboratoriais nesses períodos.

PALAVRAS-CHAVE: Bioquímica clínica. Gestação. Parto. Nascimento. Colostro.

\section{REFERENCES}

AOKI, T.; ISHII, M. Hematological and biochemical profiles in peripartum mares and neonatal foals (Heavy Draft Horse). Journal of Equine Veterinary Science, Wildomar, v. 32, n. 3, p. 170-176, 2012. https://doi.org/10.1016/j.jevs.2011.08.015

AXON, J. E.; PALMER, J. E. Clinical pathology of the foal. Veterinary Clinics of North America: Equine Practice, Philadelphia, v. 24, n. 2, p. 357-385, 2008. https://doi.org/10.1016/j.cveq.2008.03.005

BARTON, M. H. How to interpret common hematologic and serum biochemistry differences between neonatal foals and mature horses. In: ANNUAL CONVENTION OF THE AMERICAN ASSOCIATION OF EQUINE PRACTITIONERS. 61., 2015, Las Vegas. Proceedings... Las Vegas: American Association of Equine Practitioners (AAEP), 2015. Disponível em: <http://files.eventsential.org/b6a3b65a-f39c-4146-ae3ac5737f59fefb/event-576/91381535-Barton\%20-\%20How\%20to\%20Interpret.pdf>. Acesso em: 16 abr. 2017.

BARTON, M. H.; LEROY, B. E. Serum bile acids concentrations in healthy and clinically III neonatal foals. Journal of Veterinary Internal Medicine, Lawrence, v. 21, n. 3, p. 508-513, 2007. http://dx.doi.org/10.1111/j.1939-1676.2007.tb02998.x

BERG, E. L.; MCNAMARA, D. L.; KEISLER, D. H. Endocrine profiles of periparturient mares and their foals. Journal of Animal Science, Champaign, v. 85, n. 7, p. 1660-1668, 2007. DOI:10.2527/jas.2006-771 
BROLIO, M. P.; AMBRÓSIO, C. E.; FRANCIOLLI, A. R.; MORINI, A. C.; GUERRA, R.R.; MIGLINO, M. A. A barreira placentária e sua função de transferência nutricional. Revista Brasileira de Reprodução Animal, Belo Horizonte, v. 34, n. 4, p. 222-232, 2010.

CHAVATTE, P. Lactation in the mare. Equine Veterinary Education, Newmarket, v. 9, n. 2, p. 62-67, 1997. http://dx.doi.org/10.1111/j.2042-3292.1997.tb01279.x

CRISMAN, M. V.; SCARRATT, W. K. Immunodeficiency disorders in horses. Veterinary Clinics of North America: Equine Practice, Philadelphia, v. 24, n. 2, p. 299-310, 2008.

https://doi.org/10.1016/j.cveq.2008.03.003

ECKERSALL, P. D. Proteins, proteomics, and the dysproteinemias. In: KANEKO, J. J.; HARVEY, J. W.; BRUSS, M. L. Clinical biochemistry of domestic animals. 6th. ed. San Diego: Academic Press, 2008. p. 114155.

FAVERO, D. H. M. F.; DIAS, D. P. M.; FERINGER-JUNIOR, W. H.; BERNARDI, N. S.; LACERDA-NETO, J. C. Proteínas séricas de potros da raça Puro Sangue Árabe recém-desmamados ou com mais de trinta dias de desmame. Pesquisa Veterinária Brasileira, Rio de Janeiro, v. 31, n. supl 1, p. 89-93, Dez. 2011. http://dx.doi.org/10.1590/S0100-736X2011001300015

GIGUÈRE, S.; POLKES, A. C. Immunologic disorders in neonatal foals. Veterinary Clinics of North America: Equine Practice, Philadelphia, v. 21, n. 2, p. 241-272, 2005. DOI:

http://dx.doi.org/10.1016/j.cveq.2005.04.004

GONZÁLEZ, F. H. D.; Da SILVA, S. C. Introdução a bioquímica clínica veterinária. 2. ed. Porto Alegre: UFRGS, 2006.

HARVEY, J. W.; ASQUITH, R. L.; McNULTY, P. K.; KIVILPELTO, J.; BAUER, J. E. Clinical biochemistry of pregnant and nursing mares. Veterinary clinical pathology, Santa Barbara, v. 34, n. 3, p. 248-254, 2005. http://dx.doi.org/10.1111/j.1939-165X.2005.tb00049.x

HOWARD, D. L.; FERNANDES, W. R.; SOUZA, A. T.; LEAL, M. L. R.; MIRANDOLA, R. M. S.; BENESI, F. J. Proteína total, albumina e globulinas no plasma de potras sadias da raça brasileiro de hipismo em crescimento. Ars Veterinaria, Jaboticabal, v. 24, n. 2, p. 77-82, 2008. http://dx.doi.org/10.15361/21750106.2008v24n2p77-82

HURLEY, W. L.; THEIL, P. K. Perspectives on immunoglobulins in colostrum and milk. Nutrients, Basel, v. 3, n. 12, p. 442-474, 2011. DOI:10.3390/nu3040442

JEFFCOTT, L. B. Some practical aspects of the transfer of passive immunity to newborn foals. Equine Veterinary Journal, London, v. 6, n. 3, p. 109-115, 1974. http://dx.doi.org/10.1111/j.20423306.1974.tb03942.x

KANEKO, J. J.; HARVEY, J. W.; BRUSS, M. L. Clinical biochemistry of domestic animals. 6th. ed. San Diego: Academic Press, 2008. 928 p.

LANG, A.; SOUZA, M. V.; SALCEDO, J. H. P.; SOSSAI, S.; ARAÚJO, R. R.; LOURENÇO, G. G.; MAIA, L. Imunidade passiva em equinos: comparação entre a concentração de IgG do soro materno, colostro e soro do neonato. Revista Ceres, Viçosa, v. 54, n. 315, p. 405-411, 2007.

http://www.redalyc.org/articulo.oa?id=305226777005

MARIELLA, J.; PIRRONE, A.; GENTILINI, F.; CASTAGNETTI, C. Hematologic and biochemical profiles in Standardbred mares during peripartum. Theriogenology, Stoneham, v. 81, n. 4, p. 526-534, 2014.

https://doi.org/10.1016/j.theriogenology.2013.11.001 
MÁRQUEZ, A.; DE ABREU, J. C.; MÁRQUEZ, Y. C.; LÓPEZ, A. Perfiles lipídico y proteico en plasma de yeguas de raza cuarto de milla en diferentes etapas reproductivas. Revista Veterinaria, Corrientes, v. 25, n. 1, p. 54-57, 2014. Disponível em: <http://www.scielo.org.ar/scielo.php?script=sci_arttext\&pid=S166968402014000100011\&lng=es\&nrm=iso>. Acesso em 29 mar. 2017.

MORRESEY, P. R. Prenatal and perinatal indicators of neonatal viability. Clinical Techniques in Equine Practice, Philadelphia, v. 4, n. 3, p. 238-249, 2005. https://doi.org/10.1053/j.ctep.2005.07.005

MUÑOZ, A.; RIBER, C.; TRIGO, P.; CASTEJÓN, F. Age- and gender-related variations in hematology, clinical biochemistry, and hormones in Spanish fillies and colts. Research in Veterinary Science, London, v. 93, n. 2, p. 943-949, 2012. https://doi.org/10.1016/j.rvsc.2011.11.009

OROZCO, C. A. G.; MARTINS, C. B.; DE FREITAS D'ANGELIS, F. H.; OLIVEIRA, J. C.; LACERDANETO, J. C. Hematological values and total protein of Brasileiro de Hipismo and Breton mares during pregnancy. Ciência Rural, Santa Maria, v. 37, n. 6, p. 1695-1700, 2007. http://dx.doi.org/10.1590/S010384782000600029

ORSINI, J. A.; DIVERS, T. J. Manual of Equine Emergencies: Treatment and Procedures. 2. ed. Philadelphia: Saunders, 2003.

OUSEY, J. C. Peripartal endocrinology in the mare and foetus. Reproduction in domestic animals, Berlin, v. 39, n. 4, p. 222-231, 2004. http://dx.doi.org/10.1111/j.1439-0531.2004.00507.x

PATTERSON, W. H.; BROWN, C. M. Increase of serum $\gamma$-glutamyltransferase in neonatal Standardbred foals. American journal of veterinary Research, Chicago, v. 47, n. 11, p. 2461-2463,1986.

SATUÉ, K.; MONTESINOS, P. Plasma biochemistry in pregnant Spanish purebred broodmares. Comparative Clinical Pathology, Berlin, v. 22, n. 1, p. 113-117, 2013. DOI:10.1007/s00580-011-1375-4

SATUÉ, K.; MUÑOZ, A.; BLANCO, O. Pregnancy influences the hematological profile of Carthusian broodmares. Polish Journal of Veterinary Sciences, Warsaw, v. 13, n. 2, p. 393, 2010.

VALENTE, P. P.; CATTELAN, J. W.; SANTANA, A. E.; MALHEIROS, E. B.; DUARTE, C. A.; RASERA, L.; AITA. A. C. Concentrações de fibrinogênio plasmático, fosfatase alcalina sérica e do fibrinogênio e fosfatase alcalina no fluido peritoneal de equinos submetidos à enterorrafias aposicional e invaginante no cólon descendente. Nucleus Animalium, Ituverava, v. 1, n. 2, p. 95-106, 2009. DOI:

http://dx.doi.org/10.3738/na.v1i2.321 